Die stelling word op p. 54 gemaak dat die Britse mobiele blokhuise as die "voorloper van die eerste tenks, wat tydens die Eerste Wêreldoorlog gebou en aangewend is, beskou (kan) word." As in ag geneem word dat die mobiele blokhuise "n suiwer defensiewe doel gehad het, terwyl die tenk 'n offensiewe wapen was wat daarop gemik was om die mobiliteit op die slagveld te herstel, ten einde aan die loopgraafskaakmat te ontsnap, is dit duidelik nie 'n geldige afleiding nie.

Uit " $n$ tegniese oogpunt is daar ook ' $n$ paar kleiner puntjies wat pla. Eerstens is daar die onvolledige verwysing na foto's in die privaatversamelings van die skrywers: nóg die oorsprong van die foto's, nóg die fotograaf, of die datum van die foto's word vermeld. Verder stem die bladsyverwysings mbt hoofstuk 2 in die inhoudsopgawe nie met die teks ooreen nie, terwyl die laaste inskrywing op die lys van grootliks ongeskonde blokhuise wat op die uitvoukaart (teenoor p. 140) verskyn, gedeeltelik afgesny is.

Bovermelde kritiek ten spyt, vul Hattingh en Wessels met hierdie werk ' $n$ besondere leemte in die geskiedskrywing oor die AngloBoereoorlog. Die publikasie vat die bestaande kennis oor die Britse blokhuisstelsel in een band saam en bring bepaald ook nuwe inligting oor dié onderwerp aan die lig.

G.E. Visser, Departement Krygsgeskiedenis, Fakulteit Krygskunde, Universiteit van Stellenbosch

\title{
RHODESIAN FORCES PART I \& II (PRODUCED BY MSASA ENTERPRISES)
}

"Rhodesian Forces" is a two part video set currently being distributed by the South African based company, Msasa Enterprises. The set is the Msasa's first video release but will be followed by further titles. The videos are a compilation of footage detailing the bush war exploits of some of Rhodesia's most prestigious fighting units. 
This collection focuses on the Selous Scouts, the Special Air Service, the Rhodesian Light Infantry, the British South Africa Police the Rhodesian Air Force and the Chaplain's Corps. In addition, issues such as National Security receive attention. Most of the footage seems to have been taken from television documentaries produced by the Rhodesian Information Service. Some footage is actual live footage or news material whilst reenacted scenes have also been included. The quality of the actual video film and sound is astounding and the producers have obviously gone to great lengths to technically re-master the original celluloid transcripts.

The producers of "Rhodesian Forces" have succeeded admirably in conveying both the military and the civilian side of war. Although the content is essentially concerned with the Security Forces, the total nature of the war in Rhodesia comes through very strongly. One is afforded more than a brief glimpse of Rhodesian society at the height of the war and learns to appreciate the magnitude of the role played by the military and the war in general, in peoples' everyday lives. By the late 1970's the "bush" war was consuming the entire country. What the videos do not portray is the sense of despair and war weariness that must have been prevalent throughout the entire Rhodesian population. With the exception perhaps of the feature on the Rhodesian Corps of Chaplains, the commentary is always upbeat and optimistic. This is largely to be expected due to the nature of the footage included in this compilation. In short this is a video collection which is aimed at former Rhodesians and military enthusiasts wherever they may be. For those who fought for Rhodesia, these videos will provide a nostalgic and powerful record of the past. Many Zimbabweans on the other hand will find some of the visuals, terminology and mood of these videos outdated and most probably offensive. For the military enthusiast, they provide a rare glimpse into the tactics, terrain and sub-culture of the Rhodesian Security Forces.

Many of the units featured in this two part series have faded into the annals of history but their legends still shine brightly - for the special forces enthusiast "Rhodesian Forces" is a veritable feast - the SAS, 
Selous Scouts and the Fireforce Commandos of the Rhodesian Light Infantry are all here. Viewers are treated to an exposé of their training regimes, weaponry and bush tactics. A point of note here is what Lt Col Ron Reid-Daly refers to as "that baboon" in his book - Selous Scout; Top Secret War. Well that baboon, or another one surprisingly similar, is a star attraction in the Pamwe Chete portion of this video - I found it revolting but aspiring bush battlers would probably disagree!

It is essential to point out that not everyone is going to have an equal appreciation for the material on these cassettes. The Rhodesian Bush War was a bloody and tragic civil war. There will never be one point of view on the war or even agreement on the issues that faced Rhodesia after her Unilateral Declaration of Independence. Potential viewers need to take note of the fact that these tapes do contain some very disturbing and rather violent images. It is an acknowledged fact that the Rhodesian government believed that by airing "body counts" after Security Force operations would boost the morale of Rhodesia's population, particularly the supporters of the Rhodesian Front. As a consequence the television news footage is often far more explicit than one would have expected.

Having said that I found these videos fascinating. From the point of view of someone who is student of history and a military enthusiast, they were informative, entertaining and provided a hefty "blast from the past". Few people today can imagine what Rhodesia must have been like, indeed, there are millions of those who are unaware of the fact that a country called Rhodesia ever even existed. These videos will give you a vivid idea, even the music if fitting and thoughtfully rounded off with a Clem Tholet song at the end. For those who have read extensively on the Bush War and Southern African history, these videos provide a fascinating insight into Zimbabwean history. In some instances I had the rather eerie sensation of seeing ordinary people whose photographs I had seen in books actually gaining life on celluloid. The point is that audio-visual mediums offer one something completely different to that which books offer. I would recommend that anyone who wants to know more about Rhodesia and experience something of its atmosphere at during the 
turbulent UDI years, should make an effort to obtain a set of "Rhodesian Forces".

Msasa Enterprises actually hold a large filmatic collection of Rhodesiana and for those who are interested in gaining more information on this topic a visit to Msasa's website at www.rhodesianvideos.co.za is worthwhile. "Rhodesian Forces is available in both PAL and NTSC formats with a running time of approximately 75 minutes. My copies arrived at the Post Office in double quick time. You can order via the Internet or by writing to the following address:

Msasa Enterprises S.A.

P.O. Box 14642,

Farrarmere,

Benoni

1518 ,

South Africa

Noëlle van der Waag-Cowling, Department of Academic Development, Faculty of Military Science

\section{THE MAKING OF STRATEGY; RULERS, STATES AND WAR}

W. Murray, M. Knox, and A. Bernstein (eds.)

Cambridge University Press, Cambridge: 1997

704 pages

tables, maps

ISBN 0521566274

$£ 17-95$

The Making of Modern Strategy in the product of a spectrum of contributors working on the concept of strategy and in particular the strategy formulation processes. These contributors include not only historians but also political scientists, some of whom focus on security and strategic studies. Thus editors and contributors represent a necessary balance, as the making of strategy requires insights and understanding of both fields. Throughout the book the writers focus upon the historical 